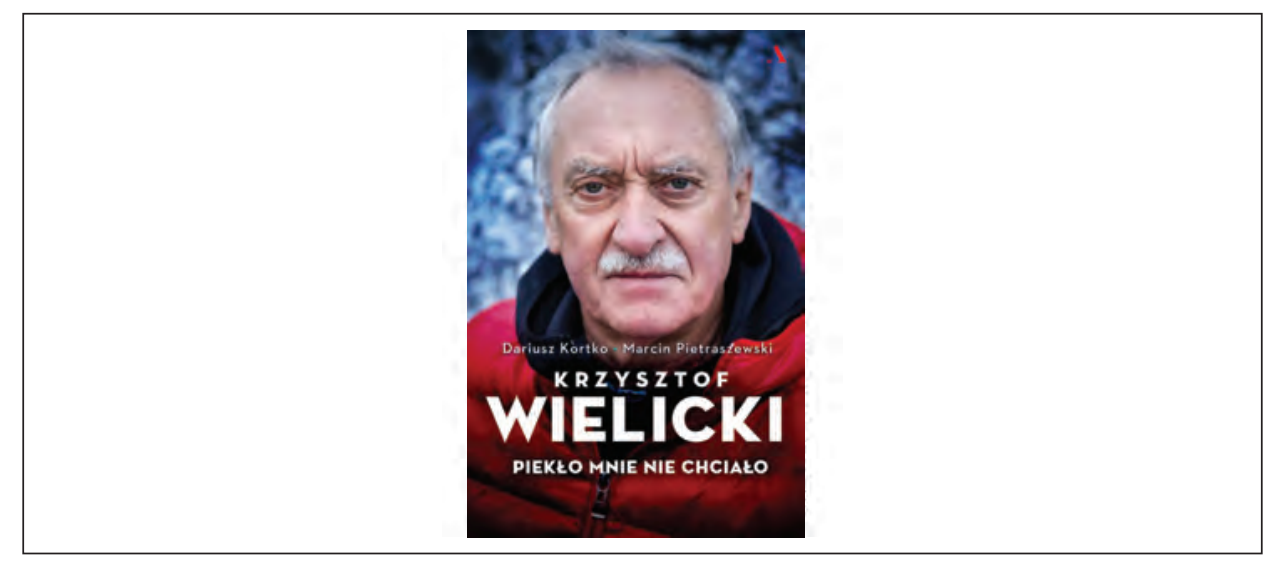

\title{
Krzysztof Wielicki — człowiek urodzony we właściwym czasie
}

https://doi.org/10.19195/2084-4107.13.32

[rec.:] Dariusz Korotko, Marcin Pietraszewski, Krzysztof Wielicki. Piekło mnie nie chciało, Wydawnictwo Agora, Warszawa 2019, ss. 437, nlb. ilustr.

Krzysztof Wielicki — a man born in the right time

Słowa-klucze: Krzysztof Wielicki, biografia, pamiętnik, wywiad, góry wysokie, himalaizm, wspinanie bing

Keywords: Krzysztof Wielicki, biography, diary, interview, high mountains, himalaism, clim-

Wydana w 2019 roku książka o wybitnym polskim himalaiście Krzysztofie Wielickim to dramatyczna i piękna opowieść o zmaganiu się z zimnem, przestrzenią, śniegiem i samym sobą, lecz także o wielu innych sprawach: o uzależnieniu od wspinaczki stanowiącej nawet w nudnym PRL-u gwarancję interesującego życia i cenie, którą się za tę pasję płaci, o środowisku klubów wysokogórskich, o ludziach i o przestrzeni. Zbudowana z pamiętnika Krzysztofa Wielickiego (wyróżniają go cudzysłowy), rozmów, okruchów wspomnień i chłodnej trzecioosobowej opowieści wielowymiarowa narracja Dariusza Korotki i Marcina Pietraszewskiego przykuwa uwagę czytelnika od pierwszej strony i buduje nastrój pełen napięcia. Wzmacniają go zdjęcia z archiwum Krzysztofa Wielickiego, tworzące jakby drugi ciąg opowiadania, który sprawia, że obraz podkreśla sens słów, a zarazem świetnie je ilustruje. Budowaniu tego napięcia służy też częsta zmiana technik narracyjnych: raz są zwarte reportaże, krótkie biografie rodzinne, raz ostre dialogi, czasem refleksja prawie aforystyczna, kiedy indziej spokojna relacja. W momen- 
tach największego napięcia, przy podchodzeniu do szczytu, narracja staje się coraz bardziej powściągliwa, jakby „zamarznięta” — widać autorzy książki są świadomi, że wobec tego, co dzieje się w górach, słowa stają się banalne.

Jest w tej książce cała poezja i proza wspinania, sprawy przyziemne, nawet trywialne i podniosłe, ludzie wobec ludzi i ludzie wobec gór. A góry zawsze są piękne, groźne i wyniosłe. Biografia himalaisty została wpisana w szerokie tło społeczne, środowiskowe, rodzinne, nawet polityczne, co nadaje jej głębszego wymiaru, czyni ją opowieścią o całym środowisku, jego przemianach, priorytetach moralnych, nawet zmianach aksjologicznych, w czym mieści się też dramatyczne pytanie: „Czy koniec »braterstwa liny«, czy życie drugiego człowieka nie jest ważniejsze niż zdobycie szczytu?". Dyskusja o etyce w górach, jak wszystkie rozmowy o sytuacjach granicznych, pozostaje bez odpowiedzi i w tej publikacji, choć pytania zostają postawione ostro i jednoznacznie. Według Wandy Rutkiewicz Himalaje wypaczyły idee alpinizmu, podczas gdy Manifest Wielickiego ogłoszony w „Taterniku” w 2001 roku ogłasza nieuchronną zmianę pokoleniową.

Książka ta jest też swoistym studium życia w Polsce, najpierw Ludowej, z jej paradoksami i upokorzeniami, potem opisem niełatwych pierwszych lat po transformacji ustrojowej, nie tyle przez na przykład nazwiska polityków, ile przez opis warunków życia. Wprawdzie pojawia się Władysław Gomułka i Edward Gierek, Dziady Dejmka i marzec '68, stan wojenny i Wolna Europa, początki „Solidarności”, a także Jan Paweł II, ale to wszystko raczej służy ukazaniu wszystkich trudów związanych z organizowaniem wypraw, niż jest tematem samo w sobie. Z wyjazdami łączy się też poznawanie świata, obszarów bogactwa i nędzy, szok przeżyty w Bombaju! I drugie zdziwienie, że wszędzie spotkać można Polaków.

$\mathrm{Na}$ takim tle poznajemy całą drogę życiową przyszłego himalaisty. Dom rodzinny, szkołę i fascynację harcerstwem (dla wielu taterników czy alpinistów droga $\mathrm{w}$ góry również wiodła przez harcerstwo ${ }^{1}$ ), poznanie smaku górskiej wędrówki, nawet zdobycie trudnej sprawności „trzy pióra”, wreszcie studia i skałki w Sudetach, tam pierwsze „upadki”, a potem Tatry („najpiękniejsze na świecie”). Coraz „boleśniej”, ale też coraz ostrzej rysuje się to, co w życiu najważniejsze: taternictwo, alpinizm, himalaizm, zawsze góry, a obok nich wąską strugą płynie tak zwane normalne życie: praca zawodowa, rodzice, miłość, żona, dzieci, budowanie własnego domu, wyjazdy i powroty, znowu jakiś inny dom, inna żona, kolejne dziecko, niełatwe relacje z najbliższymi, a we wszystkim zawsze ruch i niepokój.

Spotykamy nazwiska najwybitniejszych, by wymienić tylko kilka osób: Maciej Berbeka, Adam Bilczewski, Artur Hajzer, Zygmunt Andrzej Heinrich, Wojciech Kurtyka, Jerzy Kukuczka, Reinhold Messner, Wanda Rutkiewicz, Andrzej Zawada, Ryszard Szafirski, Alex Lowe, niesforny Denis Urubko; nie sposób wszystkich wymienić - każdy został sportretowany w kilku kreskach, ale wyraziście. Wszyscy są osobowościami i mają w książce swoje osobne miejsce

${ }^{1}$ Autorzy książki najwyraźniej nie wiedzą, czym jest harcerstwo, inaczej nie napisaliby na s. 33: ,jest już za stary na harcerza”; harcerstwo nie jest kwestią wieku ani przynależnością do związku, ale postawą gotowości do niesienia pomocy „każdemu człowiekowi”. 
i wszyscy są „,wpisani” w góry, pasma górskie i szczyty, z których każde ma swoją legendę; a potem wyprawa za wyprawą według powtarzalnego scenariusza: inspiracja, szukanie pieniędzy, przygotowania, wyjazd, zawsze pełne napięć i niespodzianek. Oczywiście Alpy, ale też Alpy Południowe (Góra Cooka), Mount Everest zimą, K2, Chamonix i Francja, Dolomity, Kaukaz, Hindukusz, Pamir, „pamiętna” Annapurna, Makalu, Ganesh II i IV, Broad Peak, Manaslu, Bhagirathi II, okrutna Lhotse zimą, Korona Himalajów, Korona Ziemi, Kanczendzonga, Dhaulagiri, Gaszerbrumy, Nanga Parbat — wielki górski świat, korona wszystkiego.

Nie ma jednak nużących relacji czy „sprawozdań”, znakomita dynamika sensualistycznych opisów, skoncentrowanie na istotnych szczegółach sprawiają, że niemal słyszymy odgłos schodzącej lawiny, widzimy wschodzące słońce i czujemy zimno, wszechogarniający chłód, wyziębienie organizmu. Książka jest tak sugestywna, że niemal przeczy teorii o euforyczności uczuć czytelniczych ${ }^{2}$, bo to uczucie zimna trwa długo po zamknięciu ostatnich kart publikacji. Częstotliwość tytułowego słowa „piekło”: białe, zimne, śnieżne, z najróżniejszymi epitetami też wynika z niskiej temperatury. To „piekło" nie chciało bohatera książki, gdy podchodził na Lhotse, a oznaczało właśnie wszechogarniający mróz.

Ważny wątek stanowi przyjaźń w górach. Profesor Lech Korniszewski twierdzi, że „Nie ma trwalszej przyjaźni od tej, która utrwala się podczas górskich wypraw [...] wspólne cierpienie, radość z sukcesów, łzy porażek, zagrożenie życia, a czasem śmierć wpisana w ten sport cementują jak nic innego" (s. 219) - i właśnie to uczucie przewija się przez wszystkie stronice opowieści i przez całe życie Wielickiego, lecz także wielu innych wspinaczy. W górach najlepiej sprawdza się lojalność i odpowiedzialność drugiego człowieka, bo tam nie tylko „mierzy się siły na zamiary”, ale też prawdziwość i moc więzi międzyludzkich. „Samotne zwycięstwa smakują gorzej” — zapisuje Wielicki w swym pamiętniku (s. 138), bo ten „lodowy bojownik” w górach szuka drugiego człowieka i przemyślenia o więziach między ludźmi, zwłaszcza w sytuacjach ekstremalnych, wynikają z własnych doświadczeń. Wielicki wyznaje: ,alpinizm to przede wszystkim ludzie. Zespół daje siłę, poczucie wspólnoty, pomaga dokonywać rzeczy wielkich" (s. 409). Takie refleksje sprawiają, że książka nie jest jednym z wielu sensacyjnych bestsellerów, lecz także lekturą o filozofii wspinania, przeżywaniu gór, nawet narodowym charakterze Polaków, gdyż protagonista uważa, że wspinaczka jest skondensowaną ilustracją narodowych cnót Polaków: „umiłowania wolności, niezłomności, uporu, odwagi, solidarności, wreszcie fantazji” (s. 105).

Największe wrażenie na czytelniku robi zetknięcie się ze śmiercią w górach, czasem jest ona „białą nieprzeniknioną pustynią” (s. 18), czasem ma twarz drugiego człowieka, przyjaciela. „Śmierć to dobry moment, żeby się zatrzymać” czytamy (s. 175) — i tak zatrzymujemy się przy każdej śmierci, również tej, która przychodzi w południe, gdy jeden się kąpie, drugi czyta, a kucharz przygotowuje obiad, ale gdy się żegna kolegów, góry i tak pozostają. W książce spotykamy mnóstwo śmierci, której wspinacze wychodzili naprzeciw, ale i takiej, która bezlitośnie

\footnotetext{
2 Por. J. Pieter, Czytanie i lektura, Katowice 1960.
} 
sięgała po nich. Poprzedzają ją często dramatyczne komunikaty, rosnące napięcie, czasem milczenie i irracjonalna nadzieja czytelnika, że jednak nie! Przyciąganie szczytu jest jednak bezlitosne i człowiek musi do niego dojść za każdą cenę. Ale Wielicki twierdzi, że „góry nie zabijają, to człowiek popełnia błędy” (s. 277) w tych pięknych, mądrych słowach zwycięża jednak miłość do gór.

Bardzo bolesny jest opis śmierci Macieja Berbeki, a jeszcze gorszy moment spotkania z jego rodziną: żoną Ewą i synami, takich spotkań z rodzinami tych, którzy zostali w górach, jest więcej i zawsze są niezwykle trudne do opisania.

Całość zamyka piękna pointa na temat przyrody, która ,jest cudem, a góry czynią himalaistów świadkami tego cudu. Krajobraz górski jest tak piękny i różnorodny, że można w nim dostrzec żywą, uduchowioną istotę" (s. 420). Ta książka zapisze się trwale w długim szeregu znakomitych lektur „górskich”, obok najważniejszej z nich — legendarnego Komina pokutników Jana Długosza czy Tragedii tatrzańskich Wawrzyńca Żuławskiego wejdzie na zawsze do kanonu ważnych tekstów o sensie nie tylko wspinaczki, lecz także każdego wejścia w góry.

Krystyna Heska-Kwaśniewicz ORCID: 0000-0002-5754-3036

Uniwersytet Śląski canes@o2.pl 